Kelola

Jurnal Manajemen Pendidikan

Magister Manajemen Pendidikan

ISSN 2443-0544

FKIP Universitas Kristen Satya Wacana

Volume: 3, No. 2, Juli-Desember 2016

jurnalkelola@gmail.com

Halaman: 230-245

\title{
KOLABORASI DAN SINERGI ANTAR LEMBAGA DALAM PENINGKATAN KOMPETENSI KEPALA SEKOLAH ${ }^{1}$
}

\author{
Wasitohadi \\ Program Pascasarjana Magister Manajemen Pendidikan \\ FKIP-Universitas Kristen Satya Wacana \\ wasitohadi@staff.uksw.edu
}

\begin{abstract}
Collaboration and synergy among institutions in enhancing principal's competence is very essential. This may cover many areas, from recruitment-including the system of selection-, until certification for principal, principal candidate's training, and capacity building for principal. Optimizing role of each institutions and the parties which are involved in a collaborative and synergistic way in accordance with the systems and mechanisms, will determine the competence of the principal. This collaboration and synergy will create qualified principal according the demands and needs of autonomy in MEA era.
\end{abstract}

Keywords: Collaboration and synergy, institutions, enhancing principal's competence

\section{PENDAHULUAN}

Dalam era otonomi memasuki era MEA, kepala sekolah memiliki kedudukan dan peran yang strategis dalam upaya peningkatan mutu sekolah. Sejalan dengan pemberian otonomi yang lebih besar kepada sekolah, tugas kepala sekolah menjadi sangat menentukan dalam peningkatan mutu sekolah. Studi Bank Dunia melaporkan bahwa sekolah adalah institusi yang memegang peranan kunci dalam menentukan mutu pendidikan dasar dan kepala sekolah merupakan pelaku utama dalam memainkan peranan tersebut (Fasli Jalal \& Dedi Supriadi, 2001:155). Selain itu, berbagai studi juga menunjukkan bahwa kepala sekolah memegang kunci keberhasilan pendidikan di lembaga yang ia pimpin. Poernomosidi Hadjisarosa sebagaimana dikutip Slamet P.H (2000:4), menyatakan bahwa dari sudut manajemen, kepala sekolah merupakan sumber

\footnotetext{
${ }^{1}$ Makalah ini merupakan hasil pengembangan dari makalah yang disampaikan dalam Seminar Nasional dan Musyawarah Kerja ke V, Asosiasi Program Studi MP/AP/MPI Indonesia, dengan tema "Standarisasi KKNI Program Studi MP/AP dalam rangka Peningkatan Kompetensi Kepala/ Pengawas Sekolah di Era Masyarakat Ekonomi ASEAN”, Jumat- Minggu, 11-13 Nopember 2016 di Bengkulu.
} 
daya manusia yang bersifat sangat menentukan, karena ia sebagai manajer yang mengatur sumber daya manusia pelaksana untuk mengelola sumber daya selebihnya, sehingga proses dapat berlangsung dengan baik untuk menghasilkan output. Wayson, sebagaimana dikutip oleh Suyanto (2001: 68 ), menyatakan bahwa kepala sekolah merupakan penentu corak sekolah.

Begitu strategisnya kedudukan dan peran kepala sekolah, maka sangat mendesak untuk dipikirkan model penguatan kolaborasi dan sinergi dalam peningkatan kompetensi kepala sekolah, mulai dari proses rekrutmen calon kepala sekolah hingga pengembangan kapasitas kepala sekolah. Dengan kata lain, bila dipetakan, kepala sekolah yang tangguh, meminjam istilah Slamet P.H. (2000: 319), dapat dihasilkan jika dari sejak proses rekrutmen (bahkan sejak sebelumnya) sudah diperhatikan dengan baik syarat-syarat dan kualifikasi calon kepala sekolah itu, yakni yang sesuai dan memenuhi tuntutan dan kebutuhan era otonomi, dilanjutkan dengan pengembangan kapasitas kepala sekolah ketika calon tersebut sudah terpilih dan berkiprah menjalankan tugas pokok dan fungsinya. Dalam hal inilah segera tergambar mengenai peran lembaga-lembaga terkait. Antar lembaga tersebut harus berkolaborasi secara sinergis, dalam rangka pengembangan kompetensi kepala sekolah.

Makalah ini akan membahas mengenai kolaborasi dan sinergi antar lembaga dalam proses rekrutmen kepala sekolah (meliputi: proses pengusulan peserta program penyiapan calon kepala sekolah dan proses seleksinya), sertifikasi kepala sekolah, diklat calon kepala sekolah, dan pengembangan kapasitas kepala sekolah. Namun demikian, sebelum membahas hal tersebut, akan dibahas secara singkat tentang tugas pokok dan fungsi kepala sekolah.

\section{PEMBAHASAN}

\section{Tugas Pokok dan Fungsi Kepala Sekolah}

Tugas pokok dan fungsi kepala sekolah sering dirumuskan sebagai EMASLIM (Depdiknas,1999:15), yaitu educator (pendidik), manajer, administrator, supervisor, leader (pemimpin), inovator (pencipta), dan motivator (pendorong). Sementara itu, menurut Kepmendiknas No.162/U/2003 tentang pedoman penugasan guru sebagai kepala sekolah, peran kepala sekolah meliputi tujuh aspek, yaitu sebagai pemimpin, manajer, pendidik, administrator, wirausahawan, pencipta iklim kerja, dan penyelia. Dalam Permendiknas No. 13 Tahun 2007 tentang Standar Kepala Sekolah/Madrasah sebagai acuan bagi pengembangan kompetensi kepala sekolah/madrasah, juga ditegaskan bahwa seluruh kepala sekolah/madrasah di Indonesia 
diharapkan memiliki kompetensi yang layak sebagai kepala sekolah/madrasah. Dalam Permendiknas tersebut dinyatakan bahwa seorang kepala sekolah/madrasah diharapkan memiliki kompetensi kepribadian, manajerial, kewirausahaan, supervisi, dan sosial.

Sementara itu, dalam Permendiknas No.28 Tahun 2010 tentang penugasan guru sebagai kepala sekolah, ada tiga aspek tugas kepala sekolah, yaitu usaha pengembangan sekolah, peningkatan kualitas sekolah berdasarkan 8 (delapan) standar nasional pendidikan, dan usaha pengembangan profesionalitas sebagai kepala sekolah. Selain itu, ditegaskan juga bahwa tugas pokok dan fungsi kepala sekolah meliputi: merencanakan program, melaksanakan program, melaksanakan pengawasan, melaksanakan kepemimpinan sekolah, dan menerapkan sistem informasi sekolah.

Lebih lanjut, dikatakan bahwa seorang kepala sekolah profesional antara lain memiliki kejujuran, kompetensi yang tinggi, harapan yang tinggi (high expectation), standar kualitas kerja yang tinggi, motivasi yang kuat untuk mencapai tujuan, integritas yang tinggi, komitmen yang kuat, etika kepemimpinan yang luhur (menjadi teladan), kecintaan terhadap profesinya, kemampuan untuk berfikir strategis (strategic thinking), dan memiliki pandangan jauh ke depan (visionary). Di samping itu, kepala sekolah sebagai seorang pemimpin harus selalu berusaha memperhatikan dan mempraktekkan delapan fungsi kepemimpinan di dalam kehidupan sekolah (Wahyosumidjo, 2001:106), yaitu:

Pertama, dalam kehidupan di sekolah, kepala sekolah akan dihadapkan kepada sikap para guru, staf dan para siswa yang mempunyai latar belakang kehidupan, kepentingan serta tingkat sosial budaya yang berbeda sehingga tidak mustahil terjadi konflik antar individu bahkan antar kelompok. Dalam menghadapi hal semacam itu, kepala sekolah harus bertindak arif, bijaksana, adil, dapat memperlakukan sama terhadap orang-orang yang menjadi bawahannya, sehingga tidak terjadi diskriminasi, sebaliknya dapat diciptakan semangat kebersamaan di antara mereka. Kedua, sugesti atau saran amat diperlukan oleh para bawahan dalam melaksanakan tugas. Saran yang disampaikan dengan cara dan maksud yang benar dapat memelihara bahkan meningkatkan semangat, rela berkorban, rasa kebersamaan dalam melaksanakan tugas masing-masing.

Ketiga, kepala sekolah bertanggung jawab untuk memenuhi atau menyediakan dukungan yang diperlukan oleh para guru, staf dan siswa baik berupa dana, peralatan, waktu, bahkan suasana yang mendukung. Tanpa ada dukungan yang disediakan oleh kepala sekolah, sumber daya manusia yang ada tidak mungkin melaksanakan tugasnya dengan baik. Keempat, kepala 
sekolah berperan sebagai katalisator, dalam arti mampu menimbulkan dan menggerakkan semangat guru, staf dan siswa dalam pencapaian tujuan yang telah ditetapkan. Kelima, kepala sekolah harus dapat menciptakan rasa aman di dalam lingkungan sekolah, sehingga para guru, staf dan siswa dalam melaksanakan tugasnya merasa aman, bebas dari segala perasaan gelisah, kekhawatiran serta memperoleh jaminan keamanan dari kepala sekolah.

Keenam, seorang kepala sekolah selaku seorang pemimpin akan menjadi pusat perhatian sebagai orang yang mewakili kehidupan sekolah dimana dan dalam kesempatan apapun. Oleh sebab itu penampilan kepala sekolah harus selalu dijaga integritasnya, selalu terpercaya, dihormati baik sikap, perilaku maupun perbuatannya. Ketujuh, kepala sekolah pada hakekatnya adalah sumber semangat bagi para guru, staf dan siswa. Oleh sebab itu, kepala sekolah harus selalu membangkitkan semangat mereka sehingga mereka menerima dan memahami tujuan sekolah secara antusias, bekerja secara bertanggung jawab ke arah tercapainya tujuan sekolah. Ke delapan, kepala sekolah harus dapat menghargai apapun yang dihasilkan oleh mereka yang menjadi tanggung jawabnya. Penghargaan dan pengakuan ini dapat diwujudkan dalam berbagai bentuk, seperti kenaikan pangkat, fasilitas, kesempatan mengikuti pendidikan dan sejenisnya.

Semua peran di atas penting dan saling melengkapi dalam upaya peningkatan mutu sekolah.

Dari uraian di atas menunjukkan betapa besar dan sentralnya peran kepala sekolah itu. Sejak berlakunya otonomi daerah dengan paradigma baru yang mendasarinya, peran kepala sekolah semakin besar. Kepala sekolah menjadi lebih otonom untuk mengembangkan sekolah, dengan memanfaatkan sumber daya yang dimiliki dan mengembangkan strategi-strategi peningkatan mutu berbasis sekolah sesuai dengan kondisi setempat. Otonomi daerah, pada satu pihak, dipandang sebagai kesempatan untuk mewujudkan visi, ide, gagasan, keinginan dan harapan secara luas. Namun, di pihak lain, adanya perubahan peran tersebut membuat beban kerja kepala sekolah menjadi semakin berat. Peran kepala sekolah, lalu menjadi seperti manusia super (superman) yang harus menguasai dan sanggup melakukan banyak hal, bayangkan, ia sekaligus sebagai edukator, pemimpin, manajer, administrator, supervisor, wirausahawan, pencipta iklim kerja, penyelia, fasilitator, motivator, bahkan pimpinan proyek dan akuntan. Untuk dapat memenuhi tuntutan tersebut jelas merupakan hal yang berat. Beban kerja kepala sekolah menjadi semakin berat (Wasitohadi, 2015:190).

Menurut penelitiannya, ada sejumlah faktor mengapa perubahan peran tersebut dirasakan sebagai beban. Di samping dipengaruhi oleh kemampuan kepala sekolah untuk 
memahami perubahan yang terjadi dan implikasinya, juga tergantung dari kapasitas dan kesiapannya dalam menjalankan peran-peran baru yang dituntut oleh era otonomi. Jika pemberian otonomi kepada sekolah dan kepala sekolah tidak disertai dengan pengembangan kapasitas kepala sekolah secara memadai, maka peran-peran baru tersebut akan menjadi beban tambahan bagi kepala sekolah. Lebih-lebih, kepala sekolah yang aktif sekarang, dulunya tidak dididik dan didesain untuk menjalankan peran-peran baru tersebut, seperti peran manajerial/ kepemimpinan, dan lainnya. Dengan demikian, pemberian otonomi yang lebih besar disertai dengan pengembangan kapasitas kepemimpinan/ manajerial kepala sekolah, menjadi salah satu jalan keluar yang mutlak perlu dilakukan.

Menurut World Bank (1998), peningkatan mutu sekolah memerlukan kepala sekolah yang mampu: (a) menjabarkan sumber daya yang ada untuk menyediakan dukungan yang memadai bagi guru, bahan pengajaran yang cukup, dan pemeliharaan fasilitas yang baik; (b) memberikan waktu yang cukup untuk pengelolaan dan pengorganisasian proses instruksional; dan (c) berkomunikasi secara teratur dengan staf, orang tua, siswa, dan masyarakat terkait. Sementara, pada era sebelum otonomi, kepala sekolah negeri memiliki otonomi yang terbatas dalam mengelola sekolah dan mengalokasikan sumber daya yang diperlukan. Kebanyakan kepala sekolah juga tidak dilengkapi dengan kemampuan manajerial atau kepemimpinan yang memadai. Banyak di antara kepala sekolah yang hanya mengikuti pelatihan beberapa hari tentang teori-teori administrasi dan orientasi peraturan dan kebijakan pendidikan ketika mereka mulai menjabat sebagai kepala sekolah. Dengan kata lain, kemampuan kepala sekolah negeri belum memenuhi persyaratan mutu untuk meningkatkan efektifitas manajemen sekolah. Kondisi ini semakin menyulitkan kepala sekolah, karena sekolah negeri umumnya juga tidak memiliki otonomi yang memadai untuk meningkatkan mutu sekolah.

Selain itu, pengangkatan kepala sekolah belum didasarkan atas prestasi kerja, dan masih lebih banyak berdasarkan urutan kepangkatan. Oleh karena itu, mestinya, pemberian otonomi yang lebih besar kepada kepala sekolah, harus diikuti dengan pemilihan kepala sekolah yang baik yang memiliki ketrampilan dan karakteristik yang diperlukan untuk sekolah yang bernuansa otonomi, pemberian penghargaan terhadap kepala sekolah yang baik dan mengganti mereka yang kurang baik, dan pengembangan ketrampilan manajemen kepala sekolah. Program-program seperti ini membantu kepala sekolah untuk memahami aspek-aspek di luar peranan administrasi 
mereka yang kemudian dapat meningkatkan mutu kepemimpinan pendidikan (Wasitohadi, 2015:255)

Kepala sekolah sebagai pemimpin, dalam istilah Kotter (1996: x), adalah mesin yang mendorong perubahan (the engine that drives change), lebih-lebih dalam masyarakat yang berubah dengan cepat. Kepala sekolah sebagai agen perubahan yang mendorong dan mengelola agar semua pihak yang terkait, termotivasi dan berperan aktif dalam perubahan tersebut. Ia harus menjadi inisiatif perubahan, lalu mempengaruhi, mendorong, membimbing, mengarahkan dan menggerakkan stakeholders sekolah agar ikut bekerja mencapai tujuan sekolah. Masalahnya, obyek pengelolaan kepala sekolah tersebut demikian luasnya dan lebih banyak bersifat administratif, sehingga otonomi yang dimiliki tidak untuk memikirkan peningkatan mutu sekolah, tetapi untuk mengerjakan berbagai pekerjaan administratif yang lebih mendesak. Kata seorang kepala sekolah, yang penting "urusan birokrasi beres, soal mutu nanti”. Dengan kata lain, mesin kepemimpinan kepala sekolah, meminjam istilah Kotter, tidak dapat dipakai untuk mendorong peningkatan mutu di tingkat sekolah, tetapi justru habis untuk menyelesaikan tugastugas di luar akademik.

Pemberian otonomi kepada sekolah mestinya disertai pemberian kepercayaan kepada sekolah, dukungan sumber daya pendukung untuk melakukan otonomi itu, dan kualitas serta topangan aparat birokrasi pendidikan, sehingga sekolah lebih berkonsentrasi pada upaya peningkatan mutu sekolah. Bila tidak, maksud pemberian otonomi agar kepala sekolah lebih mampu meningkatkan mutu akan cenderung gagal total. Ini sesuai dengan pendapat Peach (1994), yang disepakati oleh Cranston (1993) dan Rizvi (1994), yang menyatakan bahwa yang utama dari otonomi sekolah adalah peningkatan manajemen sekolah untuk membebaskan pengalokasian sumber daya dari kepentingan-kepentingan yang lebih bersifat edukatif (Jalal \& Supriadi, 2001:159). Lagi pula, pemberian otonomi tersebut tidak akan menyelesaikan semua persoalan pendidikan, bahkan mungkin dapat menimbulkan masalah baru sepanjang kriteria yang ditetapkan tidak dilaksanakan sebagaimana seharusnya.

Berdasarkan deskripsi di atas, dapat disimpulkan bahwa untuk berperannya kepala sekolah dalam peningkatan mutu sekolah secara optimal dalam sekolah yang bernuansa otonomi, ada banyak faktor yang berpengaruh, seperti pemberian otonomi yang lebih besar dengan disertai pengembangan kapasitas kepala sekolah secara memadai, pemberian 
kepercayaan kepada sekolah, dukungan sumber daya pendukung untuk melakukan otonomi itu, kualitas dan topangan aparat birokrasi pendidikan dengan segala regulasi yang dibuatnya, dan bekerjanya sistem rekrutmen yang mampu memilih kepala sekolah yang tangguh. Dalam pola pikir semacam itulah, kolaborasi dan sinergi antara lembaga sangat diperlukan.

\section{Kolaborasi dan Sinergi Antar Lembaga Untuk Peningkatan Kompetensi Kepala Sekolah}

Peningkatan kompetensi kepala sekolah merupakan upaya kolaboratif-sinergistis yang melibatkan banyak lembaga. Upaya tersebut dapat terjadi pada setiap tahapan (LPPKS,17 Maret 2016) meliputi: (a) rekrutmen kepala sekolah, meliputi (1) proses pengusulan peserta program penyiapan calon kepala sekolah, (2) proses seleksi kepala sekolah (administratif dan akademik); (b) sertifikasi kepala sekolah, (c) diklat kepala sekolah, dan (d) pengembangan kapasitas kepala sekolah. Bila pada setiap tahapan tersebut, lembaga-lembaga yang terkait bisa berperan secara optimal sebagaimana seharusnya, sangat dimungkinkan akan dihasilkan seorang kepala sekolah yang kompeten, yang mampu menjawab semua tuntutan otonomi.

\section{a. Rekrutmen Kepala Sekolah}

Pada tahap ini, dibagi dalam langkah-langkah:

\section{Proses Pengusulan Peserta Program Penyiapan Calon Kepala Sekolah}

\section{Proses Pengusulan Peserta Program Penyiapan Calon Kepala Sekolah}

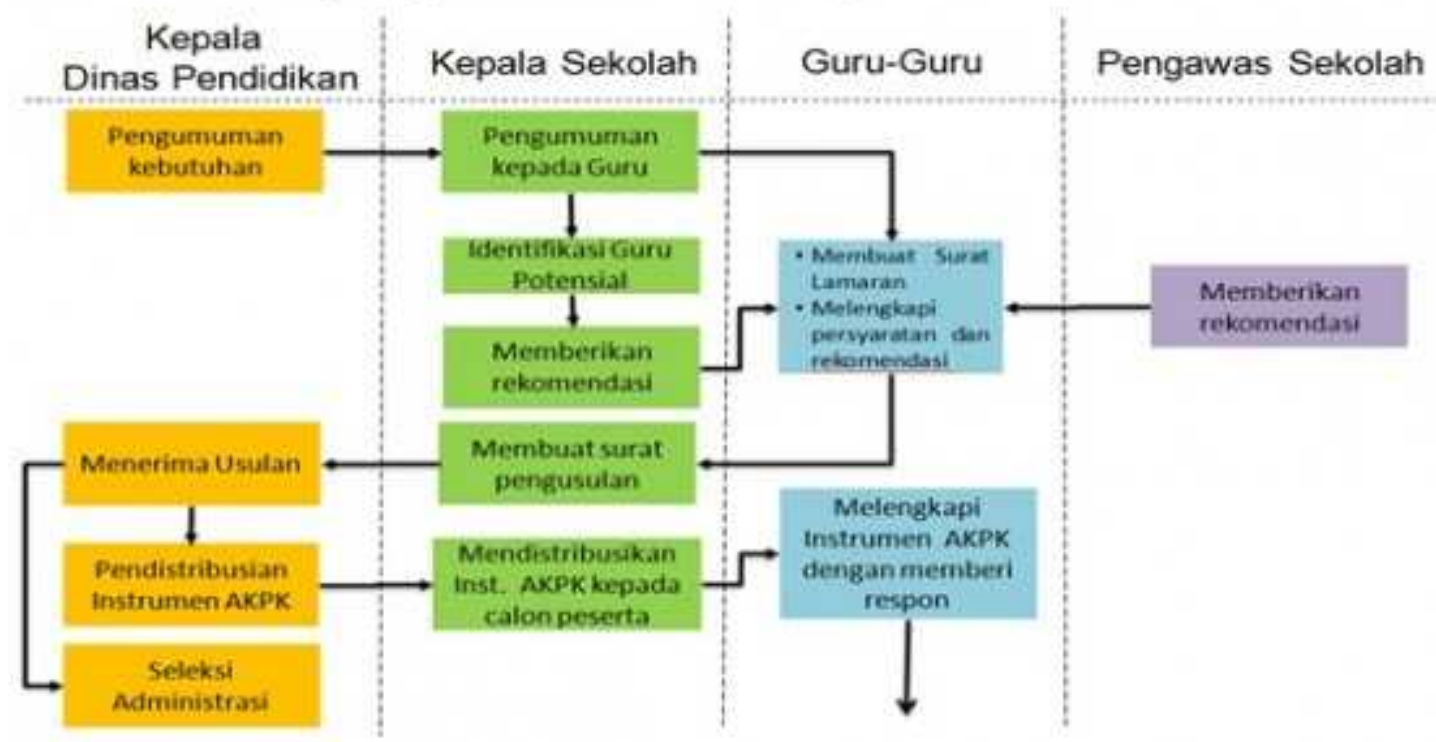

Gambar 1.

Proses Pengusulan Peserta Program 


\section{Penyiapan Calon Kepala Sekolah}

Dari gambar tersebut, dapat dipahami bahwa proses pengusulan peserta program penyiapan calon kepala sekolah mengikuti langkah-langkah: (a) Dinas Pendidikan membuat pengumuman berdasarkan proyeksi kebutuhan kepala sekolah yang telah dibuat, (b) Kepala Sekolah mengumumkan kepada guru-guru di sekolahnya untuk mengikuti seleksi calon kepala sekolah, kepala sekolah juga bisa menunjuk guru yang potensial untuk diusulkan sebagai peserta seleksi calon kepala sekolah. Kepala sekolah juga harus memberikan rekomendasi kepada guru yang sudah ditunjuk sebagai calon kepala sekolah, (c) Guru yang ditunjuk sebagai peserta calon kepala sekolah harus membuat surat lamaran dan melengkapi persyaratan yang telah ditetapkan, (d) Pengawas sekolah memberikan rekomendasi kepada guru yang mendaftar sebagai peserta seleksi calon kepala sekolah, (e) Kepala sekolah membuat usulan kepada kepala Dinas Pendidikan Guru yang direkomendasikan menjadi peserta calon kepala sekolah, (f) Dinas Pendidikan melakukan seleksi administrasi sesuai yang diamanatkan pada permendiknas nomor 28 tahun 2010, Dinas pendidikan juga harus mendistribusikan instrumen AKPK, (g) Kepala Sekolah yang diberi instrumen AKPK oleh Dinas Pendidikan mendistribusikan kepada Guru yang ditunjuk sebagai peserta seleksi calon Kepala Sekolah, (h) Guru mengisi Instrumen AKPK dan memberikan respon, kemudian instrumen tersebut dikumpulkan pada waktu seleksi Akademik.

Dari gambar di atas tampak lembaga-lembaga terkait yang terlibat dan atau para pihak yang berperan menemukan seorang calon kepala sekolah yang kompeten, yaitu kepala Dinas Pendidikan, Kepala sekolah, guru-guru, dan pengawas. Dengan perannnya masing-masing sekaligus hubungan fungsional di antara mereka, serta dengan mematuhi aturan main yang obyektif, transparan, dan konsisten, tentu itu menjadi modal untuk mendapatkan kepala sekolah yang tangguh.

\section{Proses Seleksi Kepala Sekolah}

Proses seleksi kepala sekolah mencakup seleksi administratif dan seleksi akademik. Seleksi administratif adalah salah satu tahapan dalam rekrutmen calon kepala sekolah sebelum ke tahap berikutnya yaitu seleksi akademik. Seleksi administrasi calon kepala sekolah merupakan serangkaian kegiatan untuk menilai dan menguji semua kelengkapan kebenaran dan keabsahan dokumen-dokumen pendukung kriteria administratif yang telah dikumpulkan dalam berkas pengajuan calon kepala sekolah oleh kepala sekolah yang bersangkutan. 
Dokumen administratif terdiri dari: (a) semua berkas usulan yang terdiri dari seluruh persyaratan administratif yang berkaitan dengan kualifikasi umum dan kualifikasi khusus calon kepala sekolah/Madrasah yang diajukan, dan (b) berkas portofolio yang merupakan kumpulan dokumen yang membuktikan pendidikan dan pengalaman calon kepala sekolah dalam bidang manajemen dan kepemimpinan sekolah/ Madrasah guru yang bersangkutan.

Seluruh rangkaian seleksi ini bertujuan untuk memverifikasi kelengkapan dan kebenaran berkas-berkas usulan dan portofolio yang diusulkan oleh calon kepala sekolah. Seseorang dinyatakan lulus seleksi administrasi apabila berkas-berkas yang dikumpulkan tersebut lengkap dan sah sesuai dengan ketentuan peraturan dan UU yang berlaku. Semua peserta yang dinyatakan lulus dalam seleksi administrasi akan diranking. Apabila peserta melebihi quota yang ada, urutan ranking akan menentukan kelulusan. Setelah peserta lulus, maka akan dilakukan pemanggilan untuk mengikuti seleksi tahap berikutnya, yaitu seleksi akademik.

Alur proses seleksi administratif tampak dalam gambar sebagai berikut.

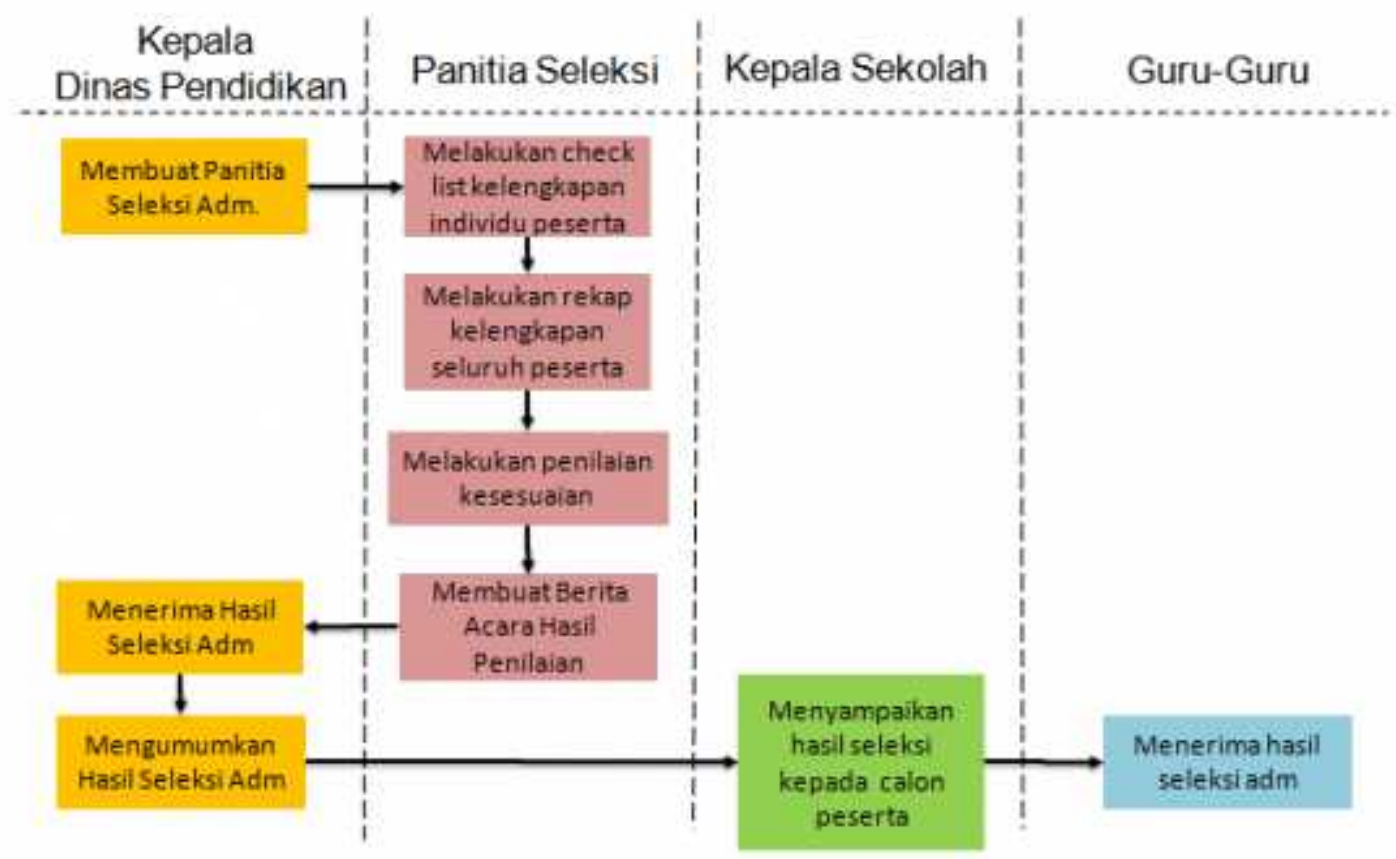

Gambar 2. Proses Seleksi Administratif Calon Kepala Sekolah

Dari gambar di atas tampak bahwa dalam tahap seleksi administratif, yang seharusnya berperan secara kolaboratif dan sinergi adalah kepala Dinas Pendidikan, panitia seleksi, kepala sekolah, dan guru-guru. Tahapannya adalah sebagai berikut: (a) Kepala Dinas Pendidikan membentuk Tim / panitia seleksi administrasi calon kepala sekolah, (b) Tim / panitia seleksi melakukan 
check list kelengkapan individu, melakukan kelengkapan rekap kelengkapan peserta dan membuat berita acara hasil penilaian seleksi administrasi, (c) Kepala Dinas pendidikan menerima hasil seleksi dari panitia seleksi administrasi dan membuat pengumuman hasil seleksi administrasi, (d) Kepala sekolah menyampaikan hasil seleksi administrasi kepada calon peserta, dan (e) Guru menerima hasil seleksi administrasi. Asumsinya, kelengkapan syarat administrasi calon kepala sekolah menunjukkan sebagian "kualitas" calon itu, dan jika itu terpenuhi, diharapkan pada akhirnya mereka akan menjadi kepala sekolah yang kompeten.

Sementara itu, alur proses seleksi akademik calon kepala sekolah tampak dalam gambar berikut.

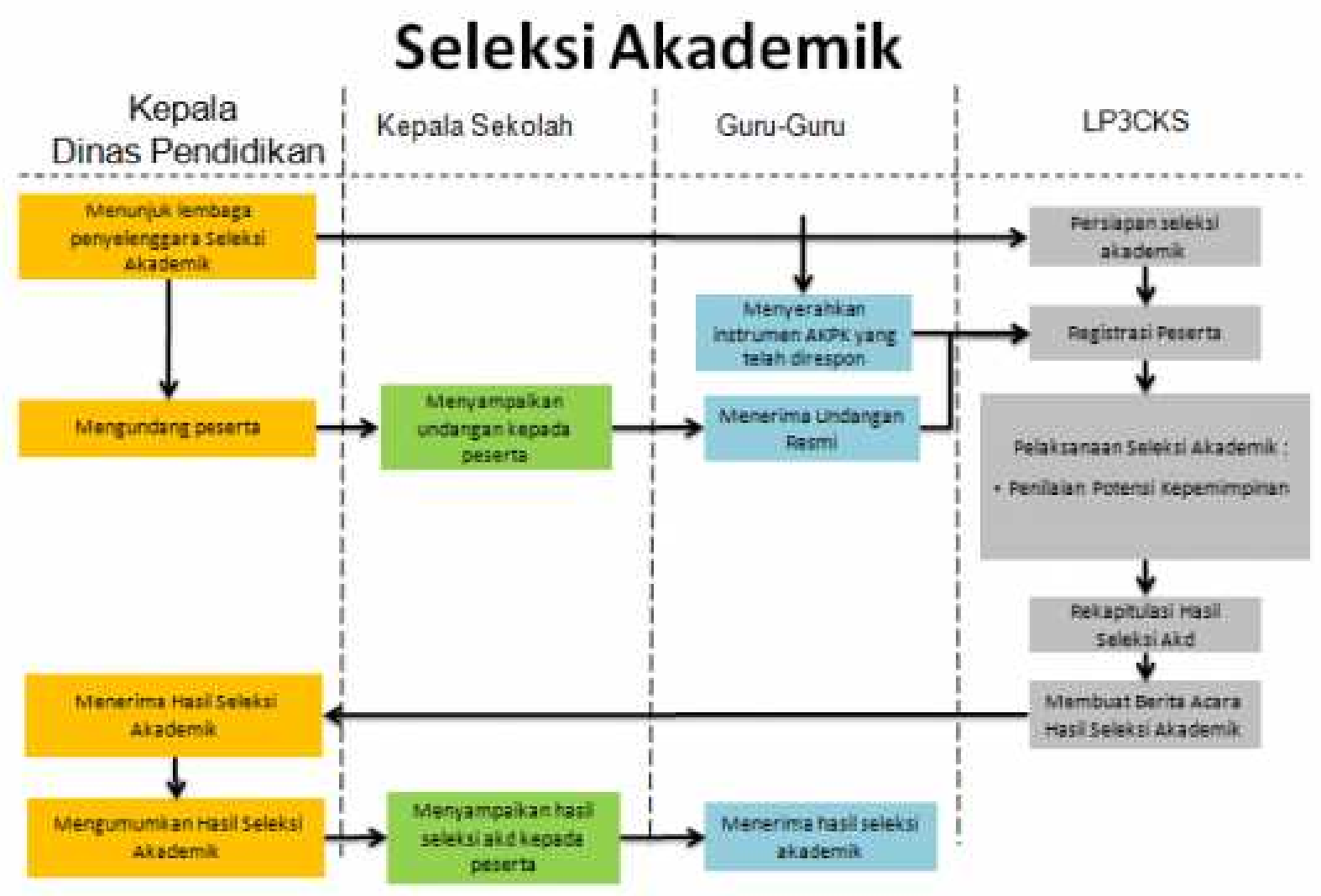

Gambar 3. Proses Seleksi Akademik Calon Kepala Sekolah

Dari gambar di atas, proses seleksi akademik calon kepala sekolah, secara ideal akan mengikuti langkah sebagai berikut: (a) Kepala Dinas Pendidikan menunjuk Lembaga Penyelenggara seleksi akademik (LP3CKS = Lembaga Penyelenggara Program Penyiapan Calon Kepala Sekolah), (b) LP3CKS menyiapkan seleksi akademik, (c) Kepala Dinas Pendidikan membuat undangan untuk 
peserta seleksi calon kepala sekolah, (d) Kepala Sekolah menyampaikan undangan seleksi kepada gurunya yang menjadi peserta, (e) Guru menerima undangan seleksi akademik secara resmi dan menyerahkan instrumen AKPK kepada panitia di LP3CKS, (f) LP3CKS melakukan registrasi peserta seleksi dan melakukan seleksi akademik meliputi (memeriksa rekomendasi KS/PS, penilaian potensi kepemimpinan dan penilaian makalah kepemimpinan), (g) LP3CKS membuat rekapitulasi hasil seleksi akademik dan membuat berita acara hasil seleksi akademik, (h) Kepala Dinas Pendidikan menerima hasil seleksi akademik dari LP3CKS dan mengumumkan hasil seleksi akademik, (i) Kepala Sekolah menyampaikan hasil seleksi akademik kepada peserta, dan (j) Guru menerima hasil seleksi akademik.

Dalam gambar di atas, juga tampak lembaga-lembaga dan atau para pihak yang mestinya secara kolaboratif dan sinergi mengemban tugas melakukan seleksi akademik calon kepala sekolah, yaitu kepala Dinas Pendidikan, kepala sekolah, guru-guru, dan LP3CKS. Bila masingmasing mengemban tugasnya sebaik mungkin, dengan menaati mekanisme secara konsisten, tentu akan dihasilkan kepala sekolah yang kompeten.

\section{b. Sertifikasi Kepala Sekolah}

Proses sertifikasi calon kepala sekolah merupakan salah satu bagian dari tahapan pendidikan dan latihan (Diklat) calon kepala sekolah yang dilaksanakan P3KS. Proses penerbitan sertifikat kepala sekolah melibatkan dua instansi, yaitu LP2CKS yang menerbitkan Sertifikat dan LPPKS yang menerbitkan NUKS sebagai dasar dari sertifikat kepala sekolah, berikut alur skemanya: 


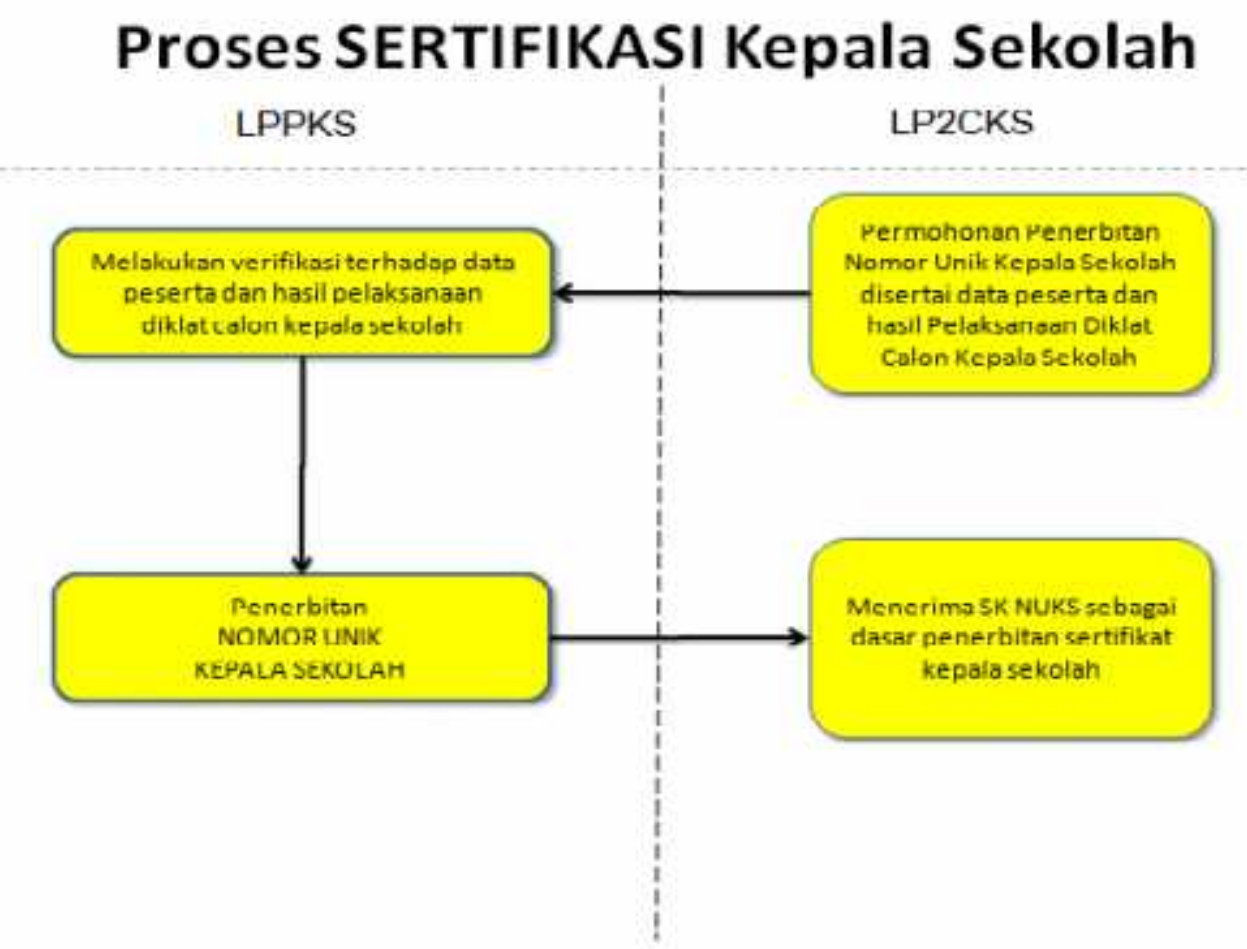

\section{Gambar 4. Proses Sertifikasi Kepala Sekolah}

Penjelasan alur proses sertifikasi kepala sekolah adalah sebagai berikut: (a) LP2CKS (Lembaga Penyelenggara Penyiapan Calon Kepala Sekolah) mengajukan permohonan kepada LPPKS untuk menerbitkan NUKS (Nomor Unik Kepala Sekolah) beserta data peserta dan hasil pelaksanaan Diklat calon Kepala Sekolah, (b) LPPKS melakukan verifikasi terhadap data peserta dan hasil pelaksanaan diklat calon kepala sekolah, (c) LPPKS menerbitkan Nomor Unik Kepala Sekolah (NUKS), dan (d) LP2CKS menerima SK NUKS sebagai dasar penerbitan sertifikat kepala sekolah. Berdasarkan alur tersebut, jelas bahwa kepala sekolah yang memiliki sertifikat sebagai kepala sekolah dipastikan memiliki Nomor Unik Kepala Sekolah (NUKS).

Dari gambar tersebut tampak bahwa lembaga yang terkait dengan proses sertifikasi kepala sekolah adalah LP2CKS dan LPPKS. Bila masing-masing berperan menjalankan tugasnya, akan diperoleh seorang kepala sekolah yang bersertifikasi, sebagai tanda bahwa yang bersangkutan merupakan kepala sekolah yang professional, yang memiliki kompetensi yang baik.

\section{c. Diklat Calon Kepala Sekolah}

Dalam Permendiknas Nomor 28 Tahun 2010 dinyatakan bahwa pendidikan dan pelatihan calon kepala sekolah/madrasah adalah proses pemberian pengalaman teoretik dan praktik kepada 
calon kepala sekolah/madrasah yang telah lulus tahap rekrutmen dalam kurun waktu yang telah ditentukan, yakni kegiatan tatap muka selama minimal 100 jam dan praktik pengalaman lapangan minimal selama 3 bulan. Sedangkan ayat (5) pada pasal yang sama menyatakan bahwa kegiatan pendidikan dan pelatihan diakhiri dengan penilaian untuk mengetahui pencapaian kompetensi calon kepala sekolah/ madrasah.

Pelaksanaan pasal tersebut diuraikan sebagai berikut: A. Model dan Tahapan Diklat Calon Kepala Sekolah/Madrasah dikemas dalam 3 tahap dengan model "In-Service Learning 1 - Onthe Job Learning - In Service Learning 2". In-Service Learning 1 (IN-1) yaitu pembelajaran melalui kegiatan tatap muka. On-the Job Learning (OJL) adalah pembelajaran di lapangan dalam situasi pekerjaan yang nyata. Sedangkan In-Service Learning 2 (IN-2) adalah kegiatan tatap muka untuk mempresentasikan dan merefleksikan hasil On the Job Learning. Model ini dirancang untuk memberikan pengalaman belajar yang terpadu antara aspek pengetahuan kognitif dan pengalaman empirik sesuai dengan karakteristik peserta Diklat sebagai adult learner.

Secara skematis, diklat calon kepala sekolah tersebut tampak sebagai berikut.

\section{Diklat Calon Kepala Sekolah}

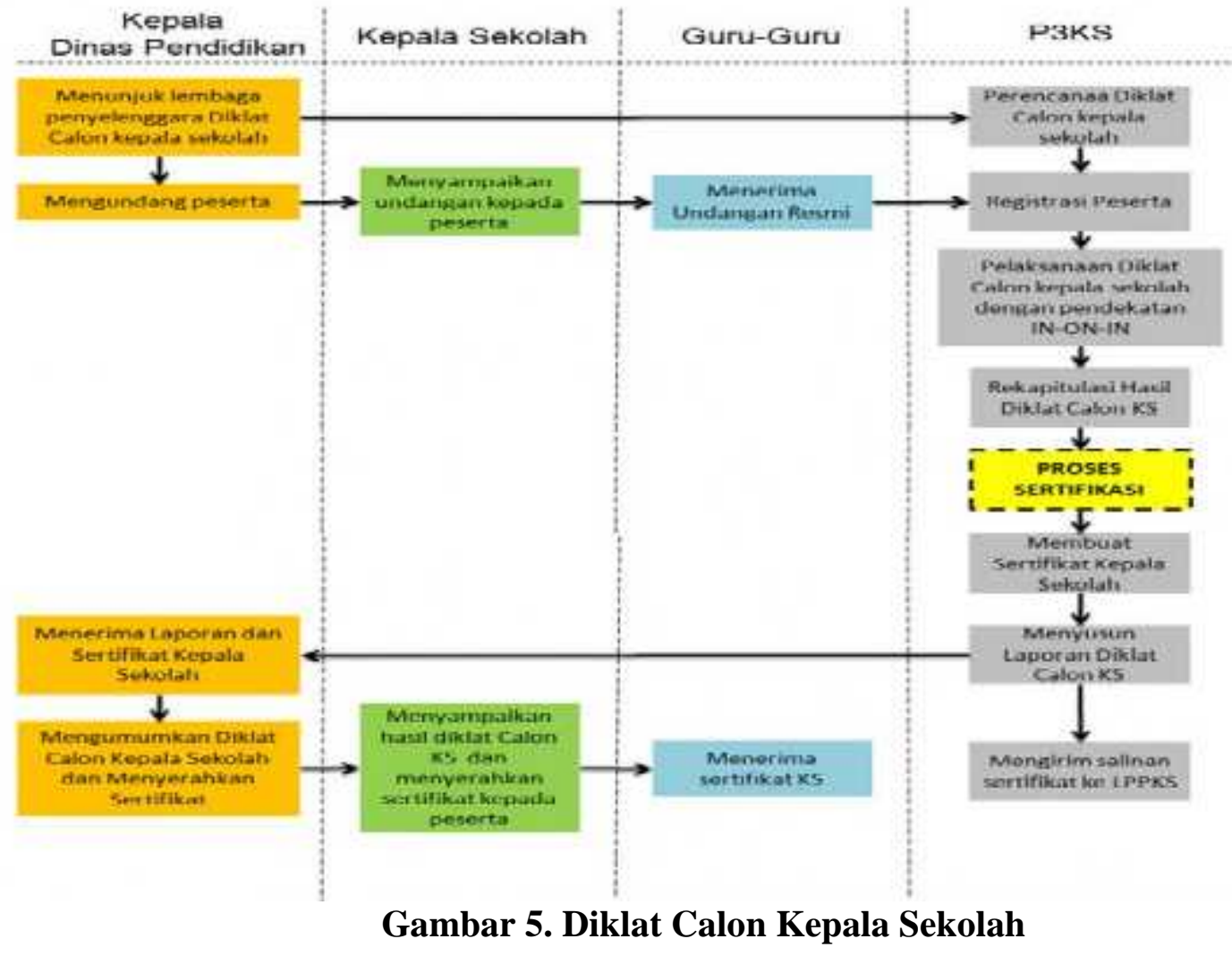


Berdasarkan skema tersebut, proses diklat kepala sekolah mengikuti tahapan sebagai berikut: (a) Kepala Dinas Pendidikan menunjuk lembaga penyelenggara diklat calon kepala sekolah (P3KS = Penyelenggara Program Penyiapan Kepala Sekolah), (b) P3KS merencanakan Diklat Calon Kepala Sekolah, (c) Kepala Dinas Pendidikan membuat undangan peserta diklat, (d) Kepala Sekolah menyampaikan undangan kepada gurunya yang mengikuti diklat CKS, (e) Guru menerima undangan diklat resmi dari Dinas Pendidikan yang disampaikan oleh kepala sekolah, (f) P3KS melaksanakan diklat calon kepala sekolah dengan pendekatan IN 1 = 70 jam $\mathrm{ON}=200$ jam IN 2 = 30 jam total 300 jam, (g) P3KS membuat rekaptulasi hasil diklat CKS, (h) P3KS melakukan proses sertifikasi (lihat bagan usulan sertifikasi), (i) P3KS menyusun laporan hasil pelaksanaan Diklat CKS dan menyerahkan ke Dinas Pendidikan, (j) Dinas Pendidikan menerima Laporan dan sertifikat Kepala Sekolah dari P3KS, (k) Dinas Pendidikan membuat pengumuman kelulusan hasil Diklat Calon Kepala Sekolah dan Menyerahkan sertifikat kepala sekolah, (1) Kepala Sekolah menyampaikan hasil diklat calon kepala sekolah dan menyerahkan sertifikat kepada peserta, (m) Peserta menerima sertifikat kepala sekolah, dan (n) P3KS mengirim salinan sertifikat ke LPPKS.

\section{d. Pengembangan Kapasitas Kepala Sekolah}

Yang dimaksud kapasitas adalah kemampuan individu dan organisasi atau unit organisasi untuk melaksanakan tugas dan fungsinya secara efektif, efisien dan berkelanjutan. Dalam hal ini, menunjuk pada pengembangan kapasitas kepala sekolah dalam melaksanakan tugas pokok dan fungsinya, kewenangan dan tanggung jawabnya, sesuai dengan tuntutan dan kebutuhan era otonomi. Tanpa pengembangan kapasitas kepala sekolah, sekolah akan mengalami banyak hambatan dalam upaya meningkatkan mutu sekolah secara efektif dan efisien.

Kepala sekolah sebagai sumber daya manusia yang mempunyai kedudukan dan peran yang strategis untuk meningkatkan mutu sekolah, diharapkan dapat menjadi pemimpin yang visioner dan transformatif, yang memiliki kapasitas dalam (Slamet P.H:2005): (a) merumuskan visi, misi, tujuan, dan strategi yang secara jelas ditulis, dipublikasikan, dan diartikulasikan ke seluruh stakeholders pendidikan, (b) meyakini bahwa unit-unit kerja pendidikan adalah tempat untuk bekerja dan belajar secara nyaman, bermakna, dan menyenangkan, (c) menghargai martabat manusia (pengikutnya) yang dibuktikan oleh penghargaan terhadap nilai-nilai inti kemanusiaan, seperti misalnya: hak asasi manusia, kedamaian, demokrasi, solidaritas/ 
kebersamaan, kecintaan/ kasih sayang, keharmonisan, keadilan, dan kesopanan, (d) memberdayakan warga unit-unit pendidikan yang dibuktikan oleh upaya-upaya nyata dalam peningkatan kemampuan dan kesanggupan kerja mereka, pemberian kewenangan dan tanggung jawab, pendidikan pekerjaan yang bermakna dan menantang, pemberian kepercayaan terhadap bawahan, dan memfasilitasi bawahan sebagai orang yang harus belajar terus, dan (e) berfikir dan bertindak secara proaktif, komunikatif, berjiwa kewirausahaan, dan berani mengambil resiko. Agar kapasitas semacam itu, sungguh-sungguh dimiliki oleh seorang kepala sekolah, selain harus memahami tuntutan-tuntutan baru era otonomi dan MEA, merumuskan kompetensi kepala sekolah yang diperlukan, juga harus mampu mengembangkan program-program pengembangan kepemimpinan kepala sekolah, yang meliputi: (a) kompetensi yang harus dimiliki seorang kepala sekolah, (b) kurikulum yang dibutuhkan, (c) tenaga pelatihnya, (d) model pelatihannya, (e) media pelatihannya, (f) tempat pelatihannya, (g) durasinya, dan (evaluasinya).

\section{SIMPULAN}

Dari pembahasan di atas, dapat disimpulkan bahwa kolaborasi dan sinergi antar lembaga dalam peningkatan kompetensi kepala sekolah sangat penting. Kolaborasi dan sinergi antar lembaga dalam peningkatan kompetensi kepala sekolah dapat terjadi pada lingkup yang sangat luas, mulai dari sejak rekrutmen, termasuk sistem seleksinya, hingga pemberian sertifikasi kepala sekolah, diklat calon kepala sekolah, dan pengembangan kapasitas kepala sekolah. Optimalisasi peran setiap lembaga dan para pihak yang terlibat secara kolaboratif dan sinergistis, sesuai dengan sistem dan mekanisme yang berlaku, akan sangat menentukan kompetensi kepala sekolah yang bersangkutan. Dengan kolaborasi dan sinergi tersebut, akan menghasilkan kepala sekolah yang memenuhi kualifikasi (qualified principal), sesuai tuntutan dan kebutuhan era otonomi di era MEA.

\section{DAFTAR PUSTAKA}

Depdiknas. 1999. Panduan manajemen sekolah. Jakarta: Depdiknas.

----------. 2007. Peraturan Mendiknas RI Nomor 13, Tahun 2007, tentang Standar Kepala Sekolah. Jakarta: Depdiknas. 2010.Peraturan Mendiknas RI Nomor 28, Tahun 2010, tentang Penugasan Guru sebagai Kepala Sekolah. Jakarta: Depdiknas.

Jalal, F. \& Supriadi, D. (Ed.). 2001. Reformasi pendidikan dalam konteks otonomi daerah. Yogyakarta: Adicita Karya Nusa. 
Kepmendiknas Nomor 162, Tahun 2003, tentang Pedoman Penugasan Guru Sebagai Kepala Sekolah.

Kotter, J. P. 1996. Leading change. Boston: Harvard Business School Press.

Lembaga Penyelenggara Penyiapan Kepala Sekolah (LPPKS), tanggal 17 Maret 2016

Slamet P.H. 2000. Karakteristik kepala sekolah tangguh. Jurnal Pendidikan dan Kebudayaan, 25, 319-332.

. 2000. Manajemen berbasis sekolah. Salatiga: Makalah yang disajikan dalam Seminar Implikasi Otonomi Daerah dalam Bidang Pendidikan, di Salatiga. . 2005. Peningkatan Mutu dan Peran Kepala Sekolah. Jakarta: Depdiknas.

Suyanto \&Abbas. 2001. Wajah dan dinamika pendidikan anak bangsa. Yogyakarta: Adicita Karya Nusa.

Wahjosumidjo. 2001. Kepemimpinan kepala sekolah. Jakarta: PT. Grafindo Persada.

Wasitohadi. 2015. Paradigma Baru Pendidikan. Salatiga: Penerbit Tisara Grafika.

World Bank. 1998. Education in Indonesia - From crisis to recovery. (Chapter 5). Education sector unit, east asia and pacific region. 